Sylwia Bąk (iD) orcid.org/0000-0003-4398-0865

Faculty of Management and Social Communication

Jagiellonian University, Kraków

\title{
RISK PROFILE OF POLISH ENTERPRISES IN THE MEDIA SECTOR LISTED ON THE WARSAW STOCK EXCHANGE
}

\begin{abstract}
Risk management currently determines the probability of survival and development of enterprises. The main aim of this article is to attempt to map the risk profile of Polish companies in the media sector listed on the Warsaw Stock Exchange (WSE) based on the categorization of risk factors identified by them. Empirical research was carried out on a sample of 15 companies listed on this Stock Exchange. The goal of empirical research was achieved through triangulation of research methods and techniques. The main method used in the research procedure was content analysis of source documents of the examined group of enterprises, mainly: annual reports (financial statements, management board reports), capital adequacy reports and other information published mandatory by WSE listed entities. The logical classification method and the comparative method in the closed comparison variant were also used. The main research findings indicate that the risk profile of the enterprises studied shows characteristics specific to the media sector that they represent.
\end{abstract}

Keywords: media sector, risk, risk profile, risk management

\section{Introduction}

Risk management is one of the key domains of contemporary management, conditioning both the opportunity to continue operations and the development of enterprises. The changing conditions of business operations have resulted in significant changes in the perception of risk management. These include, above all, the fact that risk management has become strategic because of its significant impact on obtaining and maintaining a competitive advantage, creating value for stakeholders and potential effectiveness in conditions of increasing complexity (Calandro, 2015; DeLoach, 2004; Elahi, 2013). A specific role is currently assigned to risk 
management in the era of dynamic digitization of the economy, resulting from the continuous development of new technologies, e-commerce and the impact of mass media on business operations. The result of these changes is the digital transformation of risk functions (McKinsey \& Company, 2017), which is of particular importance for enterprises operating in the media sector. The key to effective risk management in this group of enterprises seems to be the proper identification of risk factors arising as a result of the above transformations and their proper prioritization, which are the first step towards developing effective, systemic risk management in these enterprises.

The main aim of this text is to attempt to map the risk profile of Polish enterprises in the media sector, listed on the Warsaw Stock Exchange (WSE) based on the categorization of risk factors identified by these companies. The research conducted in the empirical part constitutes a significant contribution to expanding knowledge about the risk of Polish companies in the media sector listed on the Warsaw Stock Exchange. Isolating the risk profile of this group of enterprises has not been the subject of other scientific research so far. Moreover, additional motivation to undertake empirical research was to provide information on the risk profile of media sector enterprises to a wide range of stakeholders, for whom this risk information can be relevant, for example, when assessing the opportunities and threats of cooperating with a companies in this sector, or when assessing the profitability of investing in their shares.

\section{Literature Review}

A necessary condition for the effectiveness of management processes in the conditions of risk is, above all, a good understanding of the risk itself, which is possible by identifying risk factors Such identification should be a continuous process. Updating identified risk factors in adapting to changes in the environment helps to develop adequate ways of responding to the occurring risk, and thus has a positive impact on the effectiveness of the risk management process (Jedynak and Bąk, 2018). These activities should lead to the creation of a risk profile, understood as a set of identified factors/phenomena assessed as having potentially undesirable effects on the operation of the system. The creation of a risk profile enables to an indepth characterization of the sources of threats. Then created risk profile is used in the risk assessment process (Chivers et al., 2009).

Risk is considered one of the determinants of shaping social relations as well as economic relations, which is clearly confirmed in the terminology used by Ulrich Beck, who used the term "risk society" when describing the features of society (Beck, 1987). In addition, as a result of the processes of continuing globalization, which is not indifferent to the nature of risk, 25 years later, the same author modified the concept of "risk society", henceforth using the term "global risk society" 
(Beck, 2012). For business entities, regardless of their size or sectoral affiliation, risk globalization means a change in the conditions for conducting business, transforming the management processes of these entities, which should ensure the ability to survive and develop in changed operating conditions (Jedynak and Bąk, 2018). Globalization also brings a number of technological changes, that are of particular importance for international enterprises, enterprises whose activities are related to technologies and innovations, as well as for enterprises whose activity is based on continuous contacts with contractors from other countries (Petricevic and Teece, 2019). These technological changes translate into changes in communication processes, which, combined with social changes, create completely new conditions for business operations in the media sector. The participation of the media and other entities responsible for the formation and transmission of information in the creation of a "risk society" requires a specialized approach to management of specific types of threats. These threats include, inter alia: the risk of violating social norms and value systems, the risk of aggravating social inequalities, or the risk of multiplying economic crises (Piechota, 2009).

Risk management in some way determines the operation of companies in the media sector and has a crucial impact on their results. Moreover, effective risk management systems integrated with strategy allow to prevent internal crises or mitigate the negative effects if they occur (Gephart et al., 2018). In the economic aspect of the media, emphasis is therefore placed on assessing the degree of exposure to risk and on effective ways to reduce such risk or transfer it to third parties/entities (Hoskins et al., 1997; Doyle, 2002; Picard, 2002; Vogel, 2015). Therefore, proper identification and analysis of risk in this sector guarantee a better understanding of corporate strategies in the media, both in terms of the management process and content. As research by Hjort (2012) or Naficy (2012) suggests, risk in the media can be political, physical or commercial. However, according to Chalaby (2018), sources of potential losses for enterprises in this sector can be seen in seven categories of risk: catastrophic, financial, regulatory, technological, intellectual property, value chain and commercial. The same author also indicates the factors that may mitigate the consequences of risk materialization in the media sector (particularly severe for enterprises and investors), including: 1) cooperation of entities in the sector, mainly with respect to threats related to intellectual property, 2) insurance, 3) using technological innovations, 4) effective corporate strategies in the area of risk protection.

Alharthi et al. (2014) believe, in turn, that security risk is a key risk in the media sector. To limit its occurrence, the same authors propose improvements in the form of integrating risk management with the Six Sigma approach in the media industry, manifesting itself, inter alia, in the implementation of statistical tools for assessing the quality of the risk management process. In addition, technological risk is also considered a key risk in the media sector due to the observed globalization of the technological innovation market, determining changes in enterprises whose basic activity is based on technology. Technologies and their development are considered 
as strategic resources enabling the achievement of competitive growth (Teece, 1986; Freeman and Soete, 1997).

According to Stan and Duicu (2015), the new dimension of computerization and communication in the media sector, as can be currently observed, may bring enterprises many benefits related to access to modern IT and new media. However, the same authors emphasize such benefits coexist with a number of threats for managers and industry specialists, which include, inter alia: risk of quality of services/products offered, risk related to the customer (including loss of the customer), risk of contracts, information risk, competition risk and cyber risk. In turn, Syvertsen (2010) emphasizes, that new technologies and related opportunities and threats are and will be central points creating value in the media industry, while the challenge for managers will be: the need to implement adaptation activities in response to the dynamic development in innovation and the adaptation of enterprises to changes in operating conditions resulting from digitizing the economy.

In the media sector, sources of threats are also seen in connection with the use of social media by enterprises. In the studies of Khan et al. (2014), the authors point out the following risks: social risk, psychological risk and privacy risk. Privacy risk is currently a specific research problem in the digital environment. Therefore, this type of risk in the media sector requires specific procedures, strictly technical as well as social and ethical (Petrescu and Krishen, 2018). A proper approach to privacy risk management also requires specific analytical activities. Digital data privacy analysis can help build trust through solid business practices and streamline marketing activities (Martin and Murphy, 2017). In addition, scientific research indicates that a transparent and properly managed privacy policy leads in the long run to strengthening the image of the company and better perception by recipients (Krishen et al., 2017).

The approach to risk in the operations of media enterprises listed on the Stock Exchange is additionally determined by a number of formal and legal conditions arising from the internal regulations of the Stock Exchange as well as national and European legal regulations. These regulations formulate numerous requirements regarding, inter alia, obligations regarding information, the security of the companies, investors, and trading on the stock exchange, internal control and responsibility for risk management processes (Bąk, 2018).

\section{Methodology}

Empirical research was carried out in the convention of mixed methods research (Flick, 2018) using the inductive logic, inherent in the empirical approach. The aim of the research was an attempt to map the risk profile of Polish companies in the media sector listed on the Warsaw Stock Exchange (WSE). The following research questions were formulated in the research process: 
- What risk factors are identified by Polish companies in the media sector listed on the Warsaw Stock Exchange and what risk categories create these factors?

- Is the risk profile of the enterprises studied characteristic of the specificity of the sector that they represent?

The aim of the empirical research was achieved through triangulation of research methods (Flick, 2018) as a framework for combining a qualitative and quantitative approach involving mutual control of results (Hammersley, 1996). This form of combining qualitative and quantitative methods allows for an in-depth and more precise analysis of the results obtained, and thus for more accurate inference based on them. The research was divided into the following stages:

Stage 1. Selection of enterprises for research and obtaining source documents,

Stage 2. Recognition the risk factors identified by the enterprises studied,

Stage 3. Categorization of risk factors identified by the enterprises studied,

Stage 4. Demonstrating sectoral trends based on the research results received and determining the relationship between the risk profile of the enterprises studied and the specificity of the sector that they represent.

Enterprises were classified for the research through the targeted selection. Belonging to the media sector was the basic selection criterion. In addition, due to the need for access to empirical data, it was decided to classify companies listed on the Warsaw Stock Exchange, because the obligation of publishing information on risk by this group is provided by legal regulations. Thus, for the research, Polish companies listed on the Warsaw Stock Exchange representing the media sector (as of 25/06/2019) were selected - 15 companies by subsectors: radio and television (3), publishing houses (4), advertising (4), Internet portals (3), other media (1). The names of the companies selected for the study were anonymized and marked consecutively with the symbols from M1 to M15.

The main method used in the research process was the source documents analysis method (Bowen, 2008). This method allows obtaining reliable and comparable data on the risk identified by the surveyed enterprises. Data from the following documents of enterprises studied were used in the research process: annual reports (financial statements, management board reports), capital adequacy reports, reports on non-financial information, sustainability reports, integrated reports and other information published mandatory by WSE listed entities.

In addition, in order to categorize the identified risk factors, the logic classification method (Bailey, 1994; Saran, 2014) was used, which was one-dimensional, two-stage, meeting the required category selection criteria of being exhaustive and mutually exclusive. The motive of using this method is the ability to organize distributed data and thus bring them to comparability. At the final stage of the research process, the comparative analysis method (Esser and Vliegenthart, 2017) was also used in the closed comparison variant, where the units selected for comparison were matched a priori before the study (Konecki, 2000). This method allowed to 
compare the results obtained between the surveyed enterprises, and thus to illustrate sector trends. To the illustrated sector trends have a measurable dimension, quantitative tools in the form of numerical distributions of obtained test results were also used.

\section{Results}

The research process revealed nine categories of risk identified by the media sector companies listed on the Warsaw Stock Exchange: financial risk, operational risk, strategic risk, business risk, reputational risk, regulatory risk, technological risk, personnel risk and investment risk. The risk factors identified based on the analysis of source documents of the studied group of enterprises can be categorized as presented in Table 1 - that table also includes their detailed distribution.

Table 1. Distribution of risk factors identified by the enterprises studied, according to the adopted criteria of categorization

\begin{tabular}{|c|c|c|c|c|c|c|c|c|c|c|c|c|c|c|c|c|}
\hline RISK & z & $\stackrel{2}{\Sigma}$ & $\sum_{i}^{m}$ & $\sum_{i}^{H}$ & $\sum^{10}$ & $\sum_{i}^{0}$ & $\hat{\Sigma}$ & $\sum_{\Sigma}^{\infty}$ & $\hat{\Sigma}$ & $\stackrel{\circ}{\Sigma}$ & $\exists$ & $\stackrel{\mathfrak{Z}}{\Sigma}$ & $\stackrel{m}{\Sigma}$ & $\stackrel{+}{\Sigma}$ & $\stackrel{n}{\Sigma}$ & 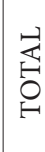 \\
\hline \multicolumn{17}{|l|}{ FINANCIAL RISK } \\
\hline Interest rate risk & $\checkmark$ & $\checkmark$ & $\checkmark$ & $\checkmark$ & $\checkmark$ & $\checkmark$ & $\checkmark$ & $\checkmark$ & & & $\checkmark$ & $\checkmark$ & & $\checkmark$ & & 11 \\
\hline Currency risk & $\checkmark$ & $\checkmark$ & & $\checkmark$ & $\checkmark$ & $\checkmark$ & $\checkmark$ & $\checkmark$ & $\checkmark$ & & $\checkmark$ & $\checkmark$ & $\checkmark$ & & & 11 \\
\hline Price risk & $\checkmark$ & & $\checkmark$ & $\checkmark$ & & & & $\checkmark$ & & $\checkmark$ & & & & $\checkmark$ & & 6 \\
\hline $\begin{array}{l}\text { Risk of losing financial } \\
\text { liquidity }\end{array}$ & $\checkmark$ & $\checkmark$ & & $\checkmark$ & $\checkmark$ & $\checkmark$ & $\checkmark$ & $\checkmark$ & & & $\checkmark$ & $\checkmark$ & $\checkmark$ & $\checkmark$ & & 11 \\
\hline $\begin{array}{l}\text { Credit risk (risk related to } \\
\text { providing additional sources } \\
\text { of financing and the risk of } \\
\text { creditworthiness of contrac- } \\
\text { tors) }\end{array}$ & $\checkmark$ & & $\checkmark$ & $\checkmark$ & $\checkmark$ & $\checkmark$ & & $\checkmark$ & & & $\checkmark$ & $\checkmark$ & $\checkmark$ & $\checkmark$ & $\checkmark$ & 11 \\
\hline $\begin{array}{l}\text { Risk related to insufficient } \\
\text { insurance coverage }\end{array}$ & & & & & $\checkmark$ & & & & & & & & & & & 1 \\
\hline \multicolumn{17}{|l|}{ OPERATIONAL RISK } \\
\hline $\begin{array}{l}\text { Risk related to the implemen- } \\
\text { tation of projects (risk } \\
\text { of incurring losses as } \\
\text { a result of improper or } \\
\text { unreliable internal processes, } \\
\text { human factors, management } \\
\text { systems or external events) }\end{array}$ & & & & $\checkmark$ & $\checkmark$ & & & $\checkmark$ & $\checkmark$ & & $\checkmark$ & & $\checkmark$ & & $\checkmark$ & 7 \\
\hline
\end{tabular}




\begin{tabular}{|c|c|c|c|c|c|c|c|c|c|c|c|c|c|c|c|c|}
\hline \multicolumn{17}{|l|}{ STRATEGIC RISK } \\
\hline $\begin{array}{l}\text { Risk of failure to achieve } \\
\text { strategic goals (strengthening } \\
\text { the position on the domestic } \\
\text { market and expansion on } \\
\text { global markets, developing } \\
\text { cooperation with current and } \\
\text { new foreign partners, ensur- } \\
\text { ing business continuity) }\end{array}$ & $\checkmark$ & & & & $\checkmark$ & $\checkmark$ & & & & & $\checkmark$ & $\checkmark$ & & & $\checkmark$ & 6 \\
\hline $\begin{array}{l}\text { Macroeconomic risk (related } \\
\text { to the economic situation in } \\
\text { Poland and in the world) }\end{array}$ & $\checkmark$ & $\checkmark$ & $\checkmark$ & $\checkmark$ & $\checkmark$ & $\checkmark$ & $\checkmark$ & $\checkmark$ & $\checkmark$ & & & & & $\checkmark$ & $\checkmark$ & 11 \\
\hline $\begin{array}{l}\text { Competition risk (including } \\
\text { the risk of losing key custom- } \\
\text { ers) }\end{array}$ & $\checkmark$ & $\checkmark$ & $\checkmark$ & $\checkmark$ & $\checkmark$ & $\checkmark$ & $\checkmark$ & $\checkmark$ & $\checkmark$ & & $\checkmark$ & & $\checkmark$ & $\checkmark$ & $\checkmark$ & 13 \\
\hline \multicolumn{17}{|l|}{ BUSINESS RISK } \\
\hline $\begin{array}{l}\text { Risk related to the process of } \\
\text { acquiring new contracts and } \\
\text { customers and a decrease in } \\
\text { demand }\end{array}$ & & & & & & & & & $\checkmark$ & & $\checkmark$ & & & & & 2 \\
\hline $\begin{array}{l}\text { Risk to financial result (risk } \\
\text { of changes in operating costs, } \\
\text { customer insolvency, em- } \\
\text { ployment costs) affecting the } \\
\text { financial result and business } \\
\text { continuity }\end{array}$ & & $\checkmark$ & & $\checkmark$ & $\checkmark$ & & $\checkmark$ & $\checkmark$ & $\checkmark$ & $\checkmark$ & $\checkmark$ & & $\checkmark$ & & & 9 \\
\hline $\begin{array}{l}\text { Risk of customer concentra- } \\
\text { tion and risk of dependence } \\
\text { on major customers }\end{array}$ & & & & $\checkmark$ & $\checkmark$ & & & & & & $\checkmark$ & & & & $\checkmark$ & 4 \\
\hline $\begin{array}{l}\text { Risk related to the situation } \\
\text { in the sector (including } \\
\text { technological changes, devel- } \\
\text { opment of new technologies, } \\
\text { implementation of new prod- } \\
\text { ucts, seasonality of sale) }\end{array}$ & $\checkmark$ & & $\checkmark$ & $\checkmark$ & $\checkmark$ & $\checkmark$ & $\checkmark$ & $\checkmark$ & & & $\checkmark$ & $\checkmark$ & $\checkmark$ & $\checkmark$ & $\checkmark$ & 12 \\
\hline \multicolumn{17}{|l|}{ REPUTATIONAL RISK } \\
\hline $\begin{array}{l}\text { Risk of loss of reputation } \\
\text { (risk for revenues due to } \\
\text { a negative image or loss of } \\
\text { confidence of customers, } \\
\text { contractors, shareholders, in- } \\
\text { vestors, potential principals) }\end{array}$ & & & & & & & & & & & $\checkmark$ & & & & $\checkmark$ & 2 \\
\hline \multicolumn{17}{|l|}{ REGULATORY RISK } \\
\hline $\begin{array}{l}\text { Compliance risk (risk related } \\
\text { to the interpretation, applica- } \\
\text { tion and amendment of legal } \\
\text { provisions, including tax law) }\end{array}$ & $\checkmark$ & $\checkmark$ & $\checkmark$ & $\checkmark$ & $\checkmark$ & $\checkmark$ & $\checkmark$ & $\checkmark$ & $\checkmark$ & $\checkmark$ & $\checkmark$ & & $\checkmark$ & & $\checkmark$ & 13 \\
\hline
\end{tabular}




\begin{tabular}{|c|c|c|c|c|c|c|c|c|c|c|c|c|c|c|c|}
\hline $\begin{array}{l}\text { Legal risk (risk of incurring } \\
\text { losses as a result of unfavor- } \\
\text { able shaping of legal rela- } \\
\text { tions, unfavorable decisions } \\
\text { of courts or other bodies in } \\
\text { disputes, risk of damages and } \\
\text { risk of violating copyrights or } \\
\text { intellectual property) }\end{array}$ & & $\checkmark$ & $\checkmark$ & $\checkmark$ & & $\checkmark$ & $\checkmark$ & $\checkmark$ & $\checkmark$ & $\checkmark$ & & $\checkmark$ & $\checkmark$ & $\checkmark$ & 11 \\
\hline $\begin{array}{l}\text { Risk related to licensing } \\
\text { agreements and concessions }\end{array}$ & $\checkmark$ & $\checkmark$ & & $\checkmark$ & & & & & $\checkmark$ & & & $\checkmark$ & & $\checkmark$ & 6 \\
\hline \multicolumn{16}{|l|}{ TECHNOLOGICAL RISK } \\
\hline $\begin{array}{l}\text { Risk of IT suppliers (related } \\
\text { to external suppliers of spe- } \\
\text { cialized equipment, software } \\
\text { and IT solutions, including } \\
\text { the risk of becoming depen- } \\
\text { dent on key suppliers) }\end{array}$ & $\checkmark$ & & & $\checkmark$ & $\checkmark$ & $\checkmark$ & & & & $\checkmark$ & & $\checkmark$ & & & 6 \\
\hline $\begin{array}{l}\text { Risk of IT systems security } \\
\text { (risk of loss of personal data, } \\
\text { customer information, in- } \\
\text { cluding risk of cybercrime) }\end{array}$ & $\checkmark$ & & $\checkmark$ & & $\checkmark$ & & $\checkmark$ & & & $\checkmark$ & & $\checkmark$ & & $\checkmark$ & 7 \\
\hline $\begin{array}{l}\text { Risk of IT infrastructure fail- } \\
\text { ure (risk related to failure of } \\
\text { IT devices and systems used) }\end{array}$ & $\checkmark$ & & & & $\checkmark$ & $\checkmark$ & $\checkmark$ & & $\checkmark$ & $\checkmark$ & & $\checkmark$ & & $\checkmark$ & 8 \\
\hline \multicolumn{16}{|l|}{ PERSONNEL RISK } \\
\hline $\begin{array}{l}\text { Personnel risk (risk related to } \\
\text { the recruitment, availability } \\
\text { and professional qualifica- } \\
\text { tions of employees, their } \\
\text { fluctuation, adaptability } \\
\text { in the work environment, } \\
\text { absenteeism, loss) }\end{array}$ & $\checkmark$ & $\checkmark$ & & $\checkmark$ & & $\checkmark$ & $\checkmark$ & & $\checkmark$ & $\checkmark$ & $\checkmark$ & $\checkmark$ & $\checkmark$ & $\checkmark$ & 11 \\
\hline \multicolumn{16}{|l|}{ INVESTMENT RISK } \\
\hline $\begin{array}{l}\text { Capital market risk (risk } \\
\text { of unexpected, adverse } \\
\text { changes in the value of } \\
\text { capital investment in shares } \\
\text { and stocks), risk related to } \\
\text { the issue of own securities, } \\
\text { risk of transactions between } \\
\text { related entities or risk arising } \\
\text { from adverse changes in the } \\
\text { shareholding structure) }\end{array}$ & $\checkmark$ & & & $\checkmark$ & & $\checkmark$ & & $\checkmark$ & $\checkmark$ & $\checkmark$ & $\checkmark$ & & $\checkmark$ & $\checkmark$ & 9 \\
\hline
\end{tabular}

Source: own study. 
According to the data provided in Table 1, the most frequently risk factors identified by enterprises studied are risk from categories: 1) regulatory - compliance risk (13/15), 2) strategic - the risk of competition (13/15), and 3) business - risk related to the situation in the sector $(12 / 15)$. Notably, within the business risk category, the entities studied identify risk factors related to the situation in the sector (primarily with technological changes, development of new technologies, implementation of new products), which factors are strongly related to the specificity of the media sector. However, they also have the characteristics of business risks, and therefore the companies studied perceive their measurable impact on the financial results as well as on business continuity.

The result of knowing the risk categories created by risk factors identified by the media sector companies studied is the mapping of their risk profile (Figure 1).

\section{Figure 1. Risk profile of the media sector enterprises studied}

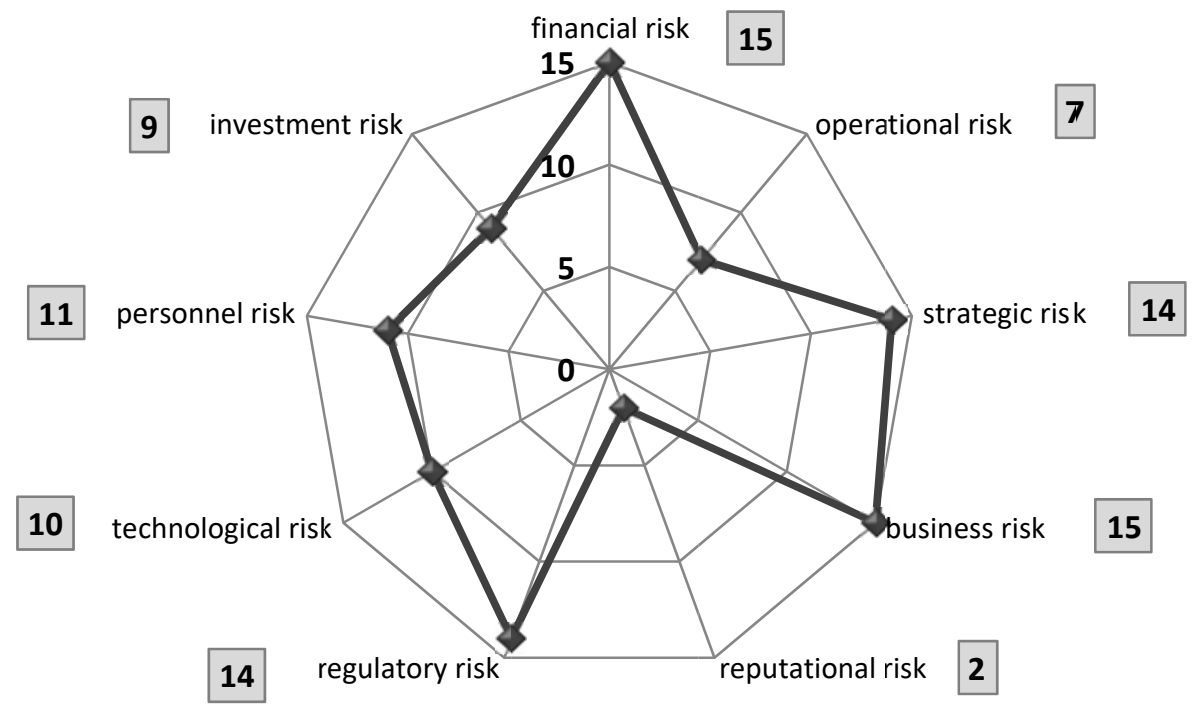

Clarification: The numbers given against the names of risk categories indicate the number of enterprises in the sector identifying the risk category.

Source: own study.

The aggregated data presented in Figure 1 shows that the risk categories identified by all surveyed enterprises are the categories of financial (15/15) and business $(15 / 15)$ risk. On the other hand, reputational risk is identified least frequently 
$(2 / 15)$. In addition, due to the specific nature of the sector, media sector enterprises distinguish three sub-categories of risk as part of the technology risk category: risk related to IT suppliers, risk of IT systems security and risk of IT infrastructure failure, thus creating a picture of sector risk. However, they identify technological risks less frequently than risks from financial, business, regulatory, strategic and personnel categories. The quantitative distribution of technological risk sub-categories (being a detailed description of the risk profile presented in Figure 1) is presented in Figure 2.

Figure 2. Distribution of technological risk factors in the enterprises studied

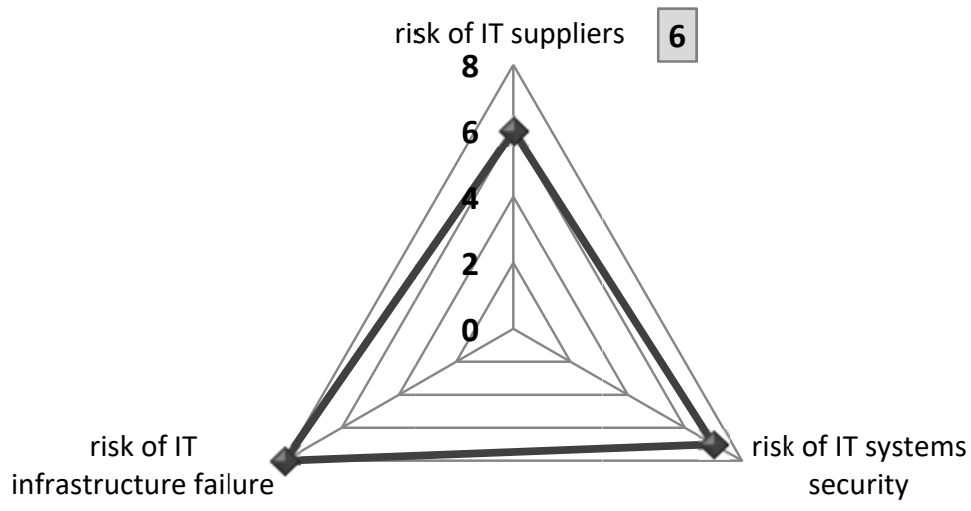

8

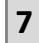

Clarification: The numbers given against the names of risk sub-categories indicate the number of enterprises in the sector identifying the risk sub-category.

Source: own study.

The data contained in Figure 2 show that the most frequently identified subcategory of technological risk among all the media sector enterprises studied is the risk of IT infrastructure failure (8/15). The risk of IT systems security (7/15) and the risk of IT suppliers (6/15) are identified slightly less frequently. 


\section{Discussion}

Determining the risk profile, understood as risk categories identified by enterprises and risk factors classified into individual categories, is one of the first steps in the process of enterprise risk management. The literature studies carried out in this text have shown a variety of possibilities for identified risks in the media sector. In turn, empirical research allowed for confronting the findings of the researchers with the results of own research conducted on a sample of 15 Polish companies in the media sector listed on the Warsaw Stock Exchange. The results of the research conducted allowed for obtaining answers to research questions and showed that the enterprises studied most often identify risk factors from regulatory category, mainly compliance risk, which is understood as potential non-compliance with external laws, WSE regulations or applicable standards (Jedynak and Bąk, 2019). Other risk factors identified by most of the enterprises studied are strategic risks, especially competition risk, which may result, inter alia, from high competition on the market of new technologies, resulting from dynamic technological changes, the development of cybernetics and the extensive phenomenon of computerization, which is also indicated in his research by Gaftea (2014). Also, business risk, related in particular to the situation in the media sector, is one of the risk factors often indicated by the enterprises studied as a source of potential threats. The level of significance of this type of risk in the operations of media sector enterprises is associated with the need to constantly adapt to uninterrupted technological progress, the emergence of new products and services, which determines the retention of existing customer groups as well as the competitive position developed in that sector. The role of risk management in maintaining a long-term competitive advantage is also pointed out by other researchers, e.g. Elahi (2013). On the other hand, Teymouri and Ashoori (2011) narrow it down to activities related to technological risk.

In addition, the aggregate risk profile of the enterprises studied, created during the research, is characteristic of the media sector that they represent. This is mainly evidenced by the identified technological risk factors, e.g. the risk of IT suppliers (which is not identified by representatives of other sectors listed on the WSE, e.g. in financial services sector and construction sector) (Bąk, 2020), which makes them media industry-specific risks. Another factor confirming the relationship of the risk profile of the enterprises studied with the represented sector is the presence of risk factors specific to this industry in other, universal risk categories (also appearing in other sectors; Bąk, 2020) - e.g. risk of the impact of changes in the market of media products and services on the results of enterprises as well as the competitive position, which is classified by enterprises to the category of business risk. 


\section{Conclusions}

The research findings can be useful both for theory and practice of risk management as a source of knowledge for various groups of stakeholders of listed companies (e.g. investors, contractors, business partners) for whom information regarding their risk profile may be important in the process of making business decisions and investment decisions (Satti et al., 2013). In addition, the sector trends indicated in the final part of the analysis of research results can be used by the managerial teams of the surveyed enterprises, e.g. in the process of comparing with competitors in terms of threats and risks related to conducting business activity and determining their competitive position in the sector on that basis. These possible implications add value to this work.

The fact that the research was based primarily on the analysis of the content of source documents of the enterprises studied could be considered as a limitation of the conducted research. Future follow-up studies using additional research methods, including, for example, interviews with representatives of the enterprises studied, may broaden the existing knowledge about the risk profile in the media sector. The sample of enterprises studied may also be expanded. It seems that basing the research on a larger sample, expanded to include companies representing the media sector that are not listed on the Warsaw Stock Exchange could increase the value of research findings.

\section{Bibliography}

Alharthi A., Fathe S.M., Aziz T. (2014). Application of Lean six sigma and risk management in entertainment and media industry. Proceedings of the International Conference on Industrial Engineering and Operations Management. Bali, Indonesia.

Bailey K.D. (1994). Typologies and Taxonomies - An Introduction to Classification Techniques. Thousand Oaks, CA: Sage Publications.

Bąk S. (2018). "Risk Management in Enterprises Listed on the Warsaw Stock Exchange: the Role of Formal and Legal Determinants”. Przedsiębiorczość i Zarządzanie, XIX, Vol. 9(3), pp. 375-391.

Bąk S. (2020). Zarządzanie ryzykiem w polskich przedsiębiorstwach notowanych na Giełdzie Papierów Wartościowych w Warszawie. Doctoral dissertation, Jagiellonian University, Faculty of Management and Social Communication, Kraków.

Beck U. (1987). Społeczeństwo ryzyka. Warszawa: PWN.

Beck U. (2012). Społeczeństwo światowego ryzyka. W poszukiwaniu utraconego bezpieczeństwa. Warszawa: Wydawnictwo Naukowe Scholar.

Bowen G.A. (2008). "Document Analysis as a Qualitative Research Method". Qualitative Research Journal, Vol. 9(2), pp. 27-40. DOI: 10.3316/QRJ0902027.

Calandro J. (2015). “A Leader's Guide to Strategic Risk Management”. Strategy \& Leadership, Vol. 43(1), pp. 26-35. DOI: 10.1108/SL-11-2014-0082. 
Chalaby J.K. (2018). "Hedging Against Disaster: Risk and Mitigation in the Media and Entertainment Industries". International Journal of Digital Television, Vol. 9(2), pp. 167-184. DOI: $10.1386 /$ jdtv.9.2.167_1.

Chivers H., Clark J.A., Cheng P-C. (2009). "Risk Profiles and Distributed Risk Assessment”. Computers \& Security, Vol. 28, pp. 521-535.

DeLoach J. (2004). “The New Risk Imperative - an Enterprise-wide Approach". Handbook of Business Strategy, Vol. 5(1), pp. 29-34.

Doyle G. (2002). Understanding Media Economics. London: Sage Publications.

Elahi E. (2013). "Risk Management: the Next Source of Competitive Advantage". Foresight, Vol. 15(2), pp. 117-131.

Esser F., Vliegenthart R. (2017). “Comparative Research Methods”. In: J. Matthe (ed.), The International Encyclopedia of Communication Research Methods (pp. 1-22). London: John Wiley \& Sons. DOI: https://doi.org/10.1002/9781118901731.iecrm0035.

Flick U. (2008). Designing Qualitative Research. Los Angeles-London-New Delhi-Singapore: Sage Publications.

Flick U. (2018). Doing Triangulation and Mixed Methods. Los Angeles-London-New DelhiSingapore: Sage Publications.

Freeman C., Soete L. (1997). The Economics of Industrial Innovation. Cambridge, MA: MIT Press.

Gaftea V. (2014). “Socio-economic Major Risks Related to the Information Technology”. Procedia Economics and Finance, Vol. 8, pp. 336-345. DOI: https://doi.org/10.1016/S22125671(14)00099-9.

Gephart R.P., Jr., Miller C.C., Helgesson K.S. (eds.) (2018). The Routledge Companion to Risk, Crisis and Emergency Management. New York: Routledge.

Hammersley M. (1996). "The relationship between qualitative and quantitative research: paradigm loyalty versus methodological eclecticism”. In: J. Richardson (ed.), Handbook of Qualitative Research Methods for Psychology and the Social Sciences (pp. 159-174). Leicester: British Psychological Society.

Hjort M. (2012). "Introduction: The Film Phenomenon and How Risk Pervades It". In: M. Hjort (ed.), Film and Risk (pp. 1-30). Detroit: Wayne State University Press.

Hoskins C., McFadyen S., Finn A. (1997). Global Television and Film: An Introduction to the Economics of the Business. Oxford: Oxford University Press.

Jedynak P., Bąk S. (2018). “The Global Risk Landscape - Its Shape, Tendencies, and Consequences for Management”. Journal of Economics \& Management, Vol. 2(32), pp. 48-59. DOI: $10.22367 /$ jem.2018.32.04.

Jedynak P., Bąk S. (2019). "Objectives of Risk Management in the Financial Services Sector the Perspective of Polish Enterprises Listed on the Warsaw Stock Exchange". Journal of Emerging Trends in Marketing and Management, Vol. 1(1), pp. 231-240.

Khan G.F., Swar B., Lee S.K. (2014). "Social Media Risks and Benefits: A Public Sector Perspective”. Social Science Computer Review, Vol. 32(5), pp. 606-627. DOI: https://doi. org/10.1177/0894439314524701.

Konecki K. (2000). Studia z metodologii badań jakościowych. Teoria ugruntowana. Warszawa: Wydawnictwo Naukowe PWN.

Krishen A.S, Raschke R.L., Close A.G., Kachroo P. (2017). “A Power-Responsibility Equilibrium Framework for Fairness: Understanding Consumers' Implicit Privacy Concerns for Location-Based Services”. Journal of Business Research, Vol. 73, pp. 20-29. DOI: 10.1016/j. jbusres.2016.12.002. 
Martin K.D., Murphy P.E. (2017). “The Role of Data Privacy in Marketing”. Journal of the Academy of Marketing Science, Vol. 45, pp. 135-155. DOI: 10.1007/s11747-016-0495-4.

McKinsey \& Company. (2017). The Future of Risk Management in the Digital Area. Retrieved from: https://www.mckinsey.com/ /media/McKinsey/Business\%20Functions/ Risk/Our\%20Insights/The\%20future\%20of\%20risk\%20management\%20in\%20the\%20 digital\%20era/Future-of-risk-management-in-the-digital-era-IIF-and-McKinsey.ashx (access: 7.02.2020).

Naficy H. (2012). "Accented Filmmaking and Risk Taking in the Age of Postcolonial Militancy, Terrorism, Globalization, Wars, Oppression, and Occupation”. In: M. Hjort (ed.), Film and Risk (pp. 143-164). Detroit: Wayne State University Press.

Petrescu M., Krishen A.S. (2018). "Analyzing the Analytics: Data Privacy Concerns”. Journal of Marketing Analytics, Vol. 6, pp. 41-43. DOI: 10.1057/s41270-018-0034-X.

Petricevic O., Teece D.J. (2019). “The Structural Reshaping of Globalization: Implications for Strategic Sectors, Profiting from Innovation, and the Multinational Enterprise". Journal of International Business Studies, Vol. 50, pp. 1487-1512. DOI: 10.1057/s41267-019-00269-x.

Picard R.G. (2002). The Economics and Financing of Media Companies. New York: Fordham.

Piechota G. (2009). "Media w społeczeństwie ryzyka”. Media, Kultura, Społeczeństwo, Vol. 1(4), pp. 147-154.

Saran J. (2014). "Classification and Typologies as Tools for Pedagogical Empirical Research Improvement”. Studia i Prace Pedagogiczne, Vol. 1, pp. 13-30.

Satti S.L., Ud Din S., Ali N. (2013). "Investor Knowledge, Risk Aversion, and Investment Decision". Actual Problems of Economics, Vol. 146(8), pp. 380-389.

Stan S., Duicu A. (2015). Best Practices in Risk Management for an Efficient Leading of Business in the Media and Advertising Industry. Proceedings of the $9^{\text {th }}$ International Management Conference "Management and Innovation for Competitive Advantage". Bucharest, Vol. 1.

Syvertsen T. (2010). "High Risk, Strong Belief. Images of the Future in the Media Industry". Nordicom Review, Vol. 31(2), pp. 3-16.

Teece D.J. (1986). “Profiting from Technological Innovation: Implications for Integration, Collaboration, Licensing and Public Policy". Research Policy, Vol. 15(6), pp. 285-305.

Teymouri M., Ashoori M. (2011). “The Impact of Information Technology on Risk Management”. Procedia Computer Science, Vol. 3, pp. 1602-1608. DOI: 10.1016/j.procs.2011.01.056.

Vogel H.L. (2015). Entertainment Industry Economics: A Guide for Financial Analysis. $9^{\text {th }}$ ed. Cambridge: Cambridge University Press. 